\title{
Я.І. Пеніикевич
}

Буковинський державний медичний університет, м. Чернівиі

\section{ІНТЕНСИВНІСТЬ ЛІЗИСУ НИЗЬКОМОЛЕКУЛЯРНИХ БІЛКІВ У ВОЛОЗІ ПЕРЕДНЬОЇ КАМЕРИ ОКА ПРИ ПРОНИКНОМУ ПОРАНЕННІ РОГІВКИ І РАЙДУЖКИ В ЕКСПЕРИМЕНТІ: ВПЛИВ ПРО- СТАГЛАНДИНІВ ТА ІНГІБІТОРІВ СИНТЕЗУ ЕЙКОЗАНОЇДІВ}

\begin{abstract}
Резюме. 3 метою вивчення впливу простагландинів, а також інгібіторів їх синтезу на протеолітичну активність вологи передньої камери ока при проникному пораненні рогівки та райдужки проведено досліди на 40 очах 40 кроликів породи Шиншила. Показано, що при проникній травмі рогівки та райдужки інтенсивність лізису низькомолекулярних білків не змінюється, проте колагеназна активність вологи передньої камери ока зростає впродовж всього періоду репаративної регенерації. Встановлено, що простагландини E1 і F2 $2 \alpha$ зменшують ступінь деградації низьомолекулярних білків, простагландин Е2 підвищує інтенсивність лізису азоальбуміну за умов зниження інтенсивності протеолітичного розпаду колагену, а парацетамол, диклофенак і дексаметазон зменшують протеоліз низькомолекулярних білків, але суттєво підвищують колагеназну активність вологи передньої камери ока у кроликів 3 травмою рогівки та райдужки.
\end{abstract}

Ключові слова: око, рогівка, райдужки, травма, простагландини, протеоліз.

Одним із найбільш частих ускладнень після травматичний запальний процес ока є тривале вивільнення біологічно активних речовин, що сприяє пошкодженню ендотелію капілярів і венул. У випадках легкого ушкодження, через гематоофтальмічний бар'єр проходять низькомолекулярні білки альбуміни, а при більш тяжких ушкодженнях глобуліни та фібриноген, що викликає утворення інтраокулярних фіброзних мембран і тяжів [1-3]. Причинами розвитку сполучної тканини можуть бути процеси організації запальних ексудатів, гемофтальму та сторонніх тіл; хронічні післятравматичні увеїти, трансформація епітелію капсули пошкодженого кришталика [4]. Встановлено, що протягом чотирьох тижнів після проникних поранень ока у волозі передньої камери ока значно зростає концентрація білка і це зумовлено порушенням бар'єрних функцій війчастого тіла та райдужки $[5,6]$.

Патоморфологічні дослідження показали, що процес регенерації проникної рани рогівки за відсутності надмірних відкладень фібрину характеризується незначною запальною реакцією, тривалість якої не перевищує 7-10 діб. Загоювання завершується утворенням негрубого безсудинного рубця $[7,8]$. Загоєння рани рогівки відбувається внаслідок регенерації власних тканин, а також репаративної організації запальних елементів. Од-нак експериментально доведено, що вже в перші хвилини після травми рана заповнюється фібрином, серед ниток якого через 2-3 години з'являються мігруючі фіброцити та фібробласти $[6,8,9]$. Таким чином, інтенсивність проліферативної реакції обернено пропорційно залежить від стану локального інтраокулярного фібринолізу-протеолізу, що визначає необхідність пошуку нових лікарських засобів, здатних підвищувати ферментативну активність у тканинах травмованого ока.

Мета дослідження: 3'ясувати вплив простагландинів, а також інгібіторів їх синтезу на протеолітичну активність вологи передньої камери ока при проникному пораненні рогівки і райдужки.

Матеріал і методи. Робота виконана на 40 кроликах породи Шиншила масою 2-2,5 кг (вік - 11,5 року). Моделювання травми ока (проникнене поранення рогівки і райдужки) проводили за асептичних умов мікрохірургічним лезом під епібульбарною анестезією 0, 5\% дікаӥном поєднано з ретробульбарною анестезією 2,0\% розчином новокаїну.

Простагландини (PG) E1, E2 та $F_{2 \alpha}$ застосовували в інстиляційних дозах відповідно: 115 нг 2 рази на день, 20 мкг одноразово і 250 нг 3 рази на день протягом трьох діб (за виключенням $P G F_{2 \alpha}$, який вводили протягом двох тижнів). Паращетамол вводили в дозі 0,5 мг, діклофенак $і$ дексаметазон - 0,05 мг упродовж двох тижнів (всі- шість разів в день).

Забір вологи передньої камери ока проводили за асептичних умов під епібульбарною анестезією 0,5\% дікаїном в динаміиі 60 денного спостереження.

Визначення протеолітичної активності у волозі передньої камери ока проводилося методом лізису азосполук з використанням реактивів "Simko Ltd." (Україна). Принциип методу полягає в тому, щуо при інкубації азоальбуміну, азоказеїну або азоколу в лужному середовищі в присутністі інгібіторів та активаторів протеолізу, які містяться у волозі передньої камери ока, відбувається ензиматичний лізис азосполук, активність якого оиінюється за сту-

(C) Пенішкевич Я.I., 2014 
пенем забарвлення інкубаційного розчину [10].

Статистична обробка отриманих даних проведена на PC IBM 586 за допомогою "Excel-7".

Результати дослідження та їх обговорення. За умов проникної травми рогівки та райдужки (табл. 1) лізис азоальбуміну на першу добу експерименту зменшувався, але потім вірогідно від контролю не вирізнявся і лише на 60 -ту добу спостережень набував значень, нижчих за контрольний рівень. Простагландин Е1 значно пригнічував про- теолітичну деградацію низькомолекулярних білків (НМБ) упродовж всього експериментального періоду, тоді як простагландин Е2 на 3-тю і 7-му доби спостережень підвищував інтенсивність розпаду олігопептидів відносно даних нелікованих тварин на 67,88 та $28,94 \%$ відповідно. Простагландин $\mathrm{F}_{2 \alpha}$ зменшував лізис азоальбуміну на 1-шу, 3-тю і 60ту доби досліду. Парацетамол пригнічував розпад НМБ лише на 7-му добу спостережень, проте порівняно з контролем лізис азо-

Таблиия 1

Динаміка змін лізису азоальбуміну (мкМ азоальбуміну на 1 мл за хв) у волозі передньої камери ока під впливом екзогенних простагландинів і при блокаді синтезу ейкозаноїдів за умов проникної травми рогівки та райдужки, $(\mathbf{x} \pm \mathbf{S x})$

\begin{tabular}{|c|c|c|c|c|c|c|}
\hline Серії досліджень & $\overline{1-а ~ д о б а ~}$ & 3-а доба & 7-а доба & 14-а доба & 28-а доба & 60-а доба \\
\hline $\begin{array}{l}\text { Контроль, } \\
\mathrm{n}=5\end{array}$ & $67,39 \pm 3,61$ & $61,50 \pm 3,66$ & $60,00 \pm 3,14$ & $62,04 \pm 2,52$ & $65,71 \pm 2,81$ & $64,62 \pm 3,53$ \\
\hline $\begin{array}{l}\text { Tравма, } \\
\mathrm{n}=5\end{array}$ & $\begin{array}{l}45,81 \pm 4,36 \\
\text { •• }\end{array}$ & $57,28 \pm 5,24$ & $71,01 \pm 7,89$ & $75,73 \pm 5,69$ & $57,26 \pm 5,44$ & 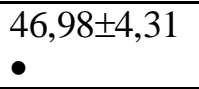 \\
\hline $\begin{array}{l}\text { Tpaвмa }+ \\
\text { PGE }_{1}, \\
n=5\end{array}$ & $\begin{array}{l}18,08 \pm 2,00 \\
\bullet \bullet \bullet \\
* *\end{array}$ & $\begin{array}{l}32,44 \pm 3,84 \\
\bullet \bullet \bullet \\
*\end{array}$ & $\begin{array}{l}12,16 \pm 1,42 \\
\bullet \bullet \bullet \\
* * *\end{array}$ & $\begin{array}{l}18,19 \pm 1,90 \\
\bullet \bullet \bullet \\
* * *\end{array}$ & $\begin{array}{l}5,90 \pm 0,81 \\
\bullet \bullet \bullet \\
* * *\end{array}$ & $\begin{array}{l}4,27 \pm 0,42 \\
\bullet \bullet \bullet \\
* * *\end{array}$ \\
\hline $\begin{array}{l}\text { Tравма + } \\
\text { PGE }_{2}, \\
n=5\end{array}$ & $63,00 \pm 6,92$ & $\begin{array}{l}96,17 \pm 10,03 \\
*\end{array}$ & $\begin{array}{l}91,57 \pm 7,04 \\
\bullet \bullet\end{array}$ & $71,00 \pm 7,45$ & $63,08 \pm 6,96$ & $51,58 \pm 6,19$ \\
\hline $\begin{array}{l}\text { Tравма }+\mathrm{PGF}_{2 \alpha}, \\
\mathrm{n}=5\end{array}$ & $\begin{array}{l}33,40 \pm 3,84 \\
\bullet \bullet \bullet\end{array}$ & 42,26士4,56 & $52,49 \pm 5,86$ & $59,46 \pm 5,29$ & $52,69 \pm 6,22$ & 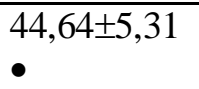 \\
\hline $\begin{array}{l}\text { Травма + параце- } \\
\text { тамол, } \\
\mathrm{n}=5\end{array}$ & $\begin{array}{l}33,18 \pm 3,64 \\
\bullet \bullet \bullet\end{array}$ & $\begin{array}{l}41,43 \pm 5,37 \\
\bullet\end{array}$ & $\begin{array}{l}49,22 \pm 5,10 \\
*\end{array}$ & $57,54 \pm 6,27$ & 49,27士5,70 & $\begin{array}{l}42,34 \pm 5,23 \\
\bullet \bullet\end{array}$ \\
\hline $\begin{array}{l}\text { Травма + дикло- } \\
\text { фенак, } \\
\text { n=5 }\end{array}$ & $\begin{array}{l}27,49 \pm 3,29 \\
\bullet \bullet \bullet \\
*\end{array}$ & $\begin{array}{l}35,54 \pm 5,03 \\
\bullet \bullet \\
*\end{array}$ & $\begin{array}{l}42,39 \pm 5,52 \\
\bullet \\
*\end{array}$ & $\begin{array}{l}49,25 \pm 6,06 \\
*\end{array}$ & $\begin{array}{l}38,90 \pm 4,98 \\
\bullet \bullet\end{array}$ & $35,55 \pm 15,46$ \\
\hline $\begin{array}{l}\text { Травма + декса- } \\
\text { метазон, } \\
n=5\end{array}$ & $\begin{array}{l}28,66 \pm 3,86 \\
\bullet \bullet \bullet \\
*\end{array}$ & $\begin{array}{l}37,80 \pm 4,80 \\
\bullet \bullet \\
*\end{array}$ & $\begin{array}{l}43,58 \pm 5,54 \\
\bullet \\
*\end{array}$ & $\begin{array}{l}51,54 \pm 6,21 \\
*\end{array}$ & $\begin{array}{l}42,35 \pm 5,39 \\
\bullet \bullet\end{array}$ & $37,82 \pm 4,34$ \\
\hline
\end{tabular}

Примітки:

- - ступінь вірогідності різниць показників відносно контролю:

$\bullet$ - $\mathrm{p}<0,05 ; \bullet \bullet-\mathrm{p}<0,01 ; \bullet \bullet \bullet-\mathrm{p}<0,001$;

* - ступінь вірогідності різниць показників відносно даних групи тварин з травмою ока без лікування:

$*$ - $\mathrm{p}<0,05 ; * *$ - $\mathrm{p}<0,01 ; * * *$ - $\mathrm{p}<0,001$;

$\mathrm{n}$ - кількість спостережень

альбуміну був значно меншим на 1-шу і 3-тю та на 28-му і 60-ту доби експерименту. Діклофенак і дексаметазон зменшували інтенсивність протеолізу олігопептидів протягом всього періоду їх введення - до 14-ої доби включно, але надалі лізис азоальбуміну відповідав даним нелікованих тварин.

Отже, проникна травма рогівки і райдужки на початку та наприкінці експерименту характеризується зменшенням протеолітичної деградації НМБ, що посилюється під впливом простагландину Е1, діклофенаку і дексаметазону, тоді як парацетамол зменшує лізис азоальбуміну лише на 7-му добу після травми ока. Простагландин Е2 володіє протилежним ефектом - під його впливом максимальна активація протеолітичної деструкції низькомолекуля- рні білки відбувається на 3-тю добу експерименту.

Найбільш суттєвих змін зазнавала колагеназна активність вологи передньої камери ока (табл. 2). Інтенсивність лізису азоколу була на $30-65 \%$ меншою за контроль протягом всього періоду спостережень (контроль-дослід).

Колагеназна активність у волозі передньої камери ока під впливом обох простагландинів групи Е знижувалась (див. табл. 2). Проте, якщо лізис азоколу при введенні простагландину Е2 зменшувався тільки на 3-тю добу досліду і надалі відповідав даним групи порівняння, то простагландин E1 мав тривалий і потужний ефект післядії: на 7-му добу спостережень (4-та доба після відміни препарату) колагеноліз був меншим ніж у кроликів 
Таблиия 2

Динаміка змін лізису азоколу (мкМ азоколу на 1 мл за хв) у волозі передньої камери ока під впливом екзогенних простагландинів і при блокаді синтезу ейкозаноїдів за умов проникної травми рогівки й райдужки, $(\mathbf{x} \pm \mathbf{S x})$

\begin{tabular}{|c|c|c|c|c|c|c|}
\hline Серії досліджень & 1-а доба & 3-а доба & 7-а доба & 14-а доба & 28-а доба & 60-а доба \\
\hline $\begin{array}{l}\text { Контроль, } \\
\mathrm{n}=5\end{array}$ & $1,86 \pm 0,08$ & $1,88 \pm 0,09$ & $1,82 \pm 0,07$ & $1,90 \pm 0,11$ & $1,81 \pm 0,06$ & $1,87 \pm 0,09$ \\
\hline $\begin{array}{l}\text { Травма, } \\
\mathrm{n}=5\end{array}$ & $\begin{array}{l}0,60 \pm 0,07 \\
\bullet \bullet \bullet\end{array}$ & $\begin{array}{l}0,99 \pm 0,11 \\
\bullet \bullet \bullet\end{array}$ & $\begin{array}{l}1,16 \pm 0,11 \\
\bullet \bullet \bullet\end{array}$ & $\begin{array}{l}1,23 \pm 0,08 \\
\bullet \bullet \bullet\end{array}$ & $\begin{array}{l}1,12 \pm 0.09 \\
\bullet \bullet \bullet\end{array}$ & $\begin{array}{l}0,83 \pm 0,09 \\
\bullet \bullet \bullet\end{array}$ \\
\hline $\begin{array}{l}\text { Tpaвмa + } \\
\text { PGE }_{1}, \\
\text { n=5 }\end{array}$ & $\begin{array}{l}0,55 \pm 0,06 \\
\bullet \bullet \bullet\end{array}$ & $\begin{array}{l}0,86 \pm 0,09 \\
\bullet \bullet \bullet\end{array}$ & $\begin{array}{l}0,58 \pm 0,07 \\
\bullet \bullet \bullet \\
* *\end{array}$ & $\begin{array}{l}0,62 \pm 0,08 \\
\bullet \bullet \bullet \\
* * *\end{array}$ & $\begin{array}{l}0,53 \pm 0,07 \\
\bullet \bullet \bullet \\
* * *\end{array}$ & $\begin{array}{l}0,49 \pm 0,07 \\
\bullet \bullet \bullet \\
*\end{array}$ \\
\hline $\begin{array}{l}\text { Tравма + } \\
\mathrm{PGE}_{2}, \\
\mathrm{n}=5\end{array}$ & $\begin{array}{l}0,72 \pm 0,06 \\
\bullet \bullet \bullet\end{array}$ & $\begin{array}{l}0,55 \pm 0,09 \\
\bullet \bullet \\
*\end{array}$ & $\begin{array}{l}1,66 \pm 0,13 \\
*\end{array}$ & $\begin{array}{l}1,28 \pm 0,12 \\
\bullet \bullet\end{array}$ & $\begin{array}{l}0,86 \pm 0,11 \\
\bullet \bullet \bullet\end{array}$ & $\begin{array}{l}0,65 \pm 0,08 \\
\bullet \bullet \bullet\end{array}$ \\
\hline $\begin{array}{l}\text { Tравма + } \\
\text { PGF }_{2 \alpha} \\
\text { n=5 }\end{array}$ & $\begin{array}{l}1,07 \pm 0,09 \\
\bullet \bullet \bullet \\
* *\end{array}$ & $\begin{array}{l}1,56 \pm 0,09 \\
\bullet \\
* *\end{array}$ & $\begin{array}{l}1,77 \pm 0,09 \\
* *\end{array}$ & $\begin{array}{l}4,10 \pm 0,54 \\
\bullet \bullet \\
* * *\end{array}$ & $\begin{array}{l}2,46 \pm 0,26 \\
\bullet \\
* *\end{array}$ & $\begin{array}{l}1,15 \pm 0,14 \\
\bullet \bullet\end{array}$ \\
\hline $\begin{array}{l}\text { Травма }+ \text { параце- } \\
\text { тамол, } \\
\text { n=5 }\end{array}$ & $\begin{array}{l}0,72 \pm 0,06 \\
\bullet \bullet \bullet\end{array}$ & $\begin{array}{l}1,30 \pm 0,11 \\
\bullet \bullet\end{array}$ & $\begin{array}{l}1,63 \pm 0,12 \\
*\end{array}$ & $\begin{array}{l}1,89 \pm 0,14 \\
* *\end{array}$ & $\begin{array}{l}1,23 \pm 0,11 \\
\bullet \bullet\end{array}$ & $\begin{array}{l}0,88 \pm 0,09 \\
\bullet \bullet \bullet\end{array}$ \\
\hline $\begin{array}{l}\text { Травма + дикло- } \\
\text { фенак, } \\
\mathrm{n}=5\end{array}$ & $\begin{array}{l}0,88 \pm 0,08 \\
\bullet \bullet \bullet \\
*\end{array}$ & $\begin{array}{l}1,42 \pm 0,14 \\
\bullet \\
*\end{array}$ & $\begin{array}{l}1,87 \pm 0,13 \\
* *\end{array}$ & $\begin{array}{l}2,13 \pm 0,15 \\
* * *\end{array}$ & $\begin{array}{l}1,40 \pm 0,14 \\
\text { - }\end{array}$ & $\begin{array}{l}1,00 \pm 0,11 \\
\bullet \bullet \bullet\end{array}$ \\
\hline $\begin{array}{l}\text { Травма + дексаме- } \\
\text { тазон, } \\
\text { n=5 }\end{array}$ & $\begin{array}{l}0,76 \pm 0,07 \\
\bullet \bullet \bullet\end{array}$ & $\begin{array}{l}1,35 \pm 0,14 \\
\bullet\end{array}$ & $\begin{array}{l}1,77 \pm 0,15 \\
*\end{array}$ & $\begin{array}{l}1,99 \pm 0,16 \\
* *\end{array}$ & $\begin{array}{l}1,16 \pm 0,11 \\
\bullet \bullet \bullet\end{array}$ & $\begin{array}{l}0,95 \pm 0,09 \\
\bullet \bullet \bullet\end{array}$ \\
\hline
\end{tabular}

Примітки:

- - ступінь вірогідності різниць показників відносно контролю:

• - $\mathrm{p}<0,05 ; \bullet \bullet-\mathrm{p}<0,01 ; \bullet \bullet \bullet-~ p<0,001 ;$

* - ступінь вірогідності різниць показників відносно даних групи тварин з травмою ока без лікування:

$*$ - $\mathrm{p}<0,05 ; * *$ - $\mathrm{p}<0,01 ; * * *$ - $\mathrm{p}<0,001$

$\mathrm{n}$ - кількість спостережень

групи порівняння в 2,33 раза, на 14-ту добу - в 2,36 раза, на 28-му добу - в 2,29 раза, на 60-ту добу - в 2,03 раза. Простагландин $\mathrm{F}_{2 \alpha}$ не впливав на інтенсивність протеолітичної деградації колагену до 14ої доби введення прапарату, коли відбувалось майже дворазове збільшення лізису азоколу. Парацетамол , диклофенак і дексаметазон зменшували інтенсивність протеолітичного розпаду колагену у волозі передньої камери травмованого ока 3 3-ої по 14-ту добу лікування (див. табл. 2). Отже, характерною рисою змін необмеженого протеолізу у волозі передньої камери ока при проникній травмі рогівки та райдужки $є$ тривале пригнічення колагеназної активності за сталої інтенсивності лізису низькомолекулярних протеїнів.

Отже, особливістю дії простагландину Е2 на необмежений протеоліз при проникній травмі рогівки та райдужки $€$ активація лізису низькокомолекулярних білків за пригнічення колагеназної активності тканин трамованого ока, тоді як пригнічення окислювального метаболізму арахідонової кислоти дексаметазоном супроводжується прямо протилежним ефектом.

Висновки. 1. При проникній травмі рогівки та райдужки інтенсивність лізису низькомолекулярних білків не змінюється, проте колагеназна активність вологи передньої камери ока зростає протягом всього періоду репаративної регенерації. 2. Простагландини E1 i $\mathrm{F}_{2 \alpha}$ зменшують ступінь деградації низькомолекулярних білків у волозі передньої камери ока кроликів з проникною травмою рогівки та райдужки. 3. Простагландин Е2 підвищує інтенсивність лізису азоальбуміну за умов зменшення інтенсивності протеолітичного розпаду колагену в тканинах ока при проникному пораненні рогівки та райдужки. 4. Парацетамол, диклофенак і дексаметазон зменшують протеоліз низькомолекулярних білків, але суттєво підвищують колагеназну активність вологи передньої камери ока у кроликів з травмою рогівки та райдужки.

Перспективи наукового пошуку. Проведені експериментальні дослідження доводять зміни протеолітичної деградації низькомолекулярних білків у волозі передньої камери травмованого ока, а також необхідність ії корекції сучасними медикаментозними засобами, що варто розглядати як докліінічний етап даного дослідження і потреби наступного вивчення цих процесів у клініці. 


\section{Список використаної літератури}

1. Пенішкевич Я.I. Вплив простагландинів E1, E2 та F2 стероїдних і нестероїдних протизапальних препаратів на колагенолітичну активність у волозі передньої камери ока, при проникній травмі рогівки, обтяженій гіфемою / Я.І. Пенішкевич // Медичина сьогодні і завтра. - 2002. - № 1. - С. 65-67. 2. Proteolytic processing of connective tissue growth factor in normal ocular tissues and during corneal wound healing / P.M. Robinson, T.S. Smith, D. Patel [et al.] // Invest. Ophthalmol. Vis. Sci. - 2012. - № 53(13). P.8093-8103. 3. Fibrinolysis and thrombosis of fibrinogen-modified gold nanoparticles for detection of fibrinolytic-related proteins / J.W. Jian, W.C. Chiu, H.T. Chang [et al.] // Anal Chim. Acta. - 2013. - Vol. 24(774) - P.67-72. 4. A macrocyclic calpain inhibitor slows the development of inherited cortical cataracts in a sheep model / J.D. Morton, H.Y. Lee, J.D. McDermott [et al.] // Invest. Ophthalmol. Vis. Sci. - 2013. - Vol. 14; 54(1). - P.389-395. 5. Immunohistochemical localization of urokinase-type plasminogen activator, urokinase-type plasminogen activator receptor and $\alpha 2$-antiplasmin in human corneal perforation: a case report / K. Sugioka, A. Kodama, K. Yoshida [et al.] // BMC Ophthalmol. - 2012. - Vol. 28(12). - P.60. 6. Wound-healing effect of micronized sacchachitin (mSC) nanogel on corneal epithelium / R.N. Chen, L.W. Lee, L.C. Chen [et al.] // Int. J. Nanomedicine. - 2012. - Vol. 7. - P. 4697-4706. 7. Компоненты регуляции фибринолиза и ангиогенеза на примере ожоговой неваскуляризаџии роговиџы у кроликов / Н.В. Чеснокова, Р.Б. Айсина, Л.И. Мухамедова [и др.] // Вестн. офтальмолог. - 2012. - T. 128(4). - C. 62-65. 8. Composition and proteolytic processing of corneal deposits associated with mutations in the TGFBI gene / H. Karring, K. Runager, I.B. Thøgersen [et al.] // Exp. Eye Res. - 2012. - Vol. 96(1). - P. 163-170. 9. Molecular signatures of long-lived proteins: autolytic cleavage adjacent to serine residues / S.P. Su, B. Lyons, M. Friedrich [et al.] // Aging Cell. - 2012. - Vol. 11(6). - Р. 1125-1127. 10. Кухарчук О.Л. Патогенетична роль та методи корекиії інтегративних порушень гормонально-месенджерних систем регуляції гомеостазу натрію при патології нирок : автореф. дис... д-ра мед. наук: 14.03.05 / Одеський мед. ін-т / Олександр Леонідович Кухарчук. - Одеса, 1996. - 37 с.

ИНТЕНСИВНОСТЬ ЛИЗИСА НИЗКОМОЛЕКУЛЯРНЫХ БЕЛКОВ ВЛАГИ ПЕРЕДНЕЙ КАМЕРЫ ГЛАЗА ПРИ ПРОНИКАЮЩЕМ РАНЕНИИ РОГОВИЦЫ И РАДУЖКИ В ЕКСПЕРИМЕНТЕ: ВЛИЯНИЕ ПРОСТАГЛАНДИНОВ И ИНГИБИТОРОВ СИНТЕЗА ЭЙКОЗАНОИДОВ

Резюме. С целью изучения влияния простагландинов, а также ингибиторов их синтеза на протеолитическую активность влаги передней камера глаза при проникающем ранении роговицы и радужки проведено исследование 40 глаз 40 кроликов породы Шиншилла. Показано, что при проникающем ранении роговицы и радужки интенсивность лизиса низкомолекулярных белков не изменяется, однако коллагеназная активность влаги передней камеры глаза увеличивается на протяжении всего периода репаративной регенерации. Установлено, что простагландины E1 i $\mathrm{F}_{2 \alpha}$ снижают степень деградации низкомолекулярных белков, простагландин Е2 повышает интенсивность лизиса азоальбумина при снижении интенсивности протеолитического распада коллагена, а парацетамол, диклофенак и дексаметазон снижают протеолиз низкомолекулярных белков, однако существенно повышают коллагеназную активность влаги передней камеры глаза у кроликов с ранением роговицы и радужки.

Ключевые слова: глаз, роговица, радужка, травма, простагландины, протеолиз.
EXPERIMENTAL AQUEOUS HUMOR LOWMOLECULAR PROTEIN LYSIS INTENSITY IN CASE OF PENETRATING CORNEAL AND IRIS INJURY: THE INFLUENCE OF PROSTAGLANDINS AND EICOSANOIDS SYNTHESIS INHIBITORS

Abstract. To study the influence of prostaglandins and their synthesis inhibitors on proteolytic activity of aqueous humor in case of penetrating corneal and iris injury 40 eyes of 40 chinchilla rabbits were evaluated. The intensity of low-molecular proteins lysis due to penetrating corneal and iris injury was found not to be changed, while collagen activity of aqueous humor increases throughout all period of reparative regeneration. Prostaglandins E1 and F2 $\alpha$ were found to reduce degradation degree of low-molecular proteins, prostaglandin E2 facilitates the intensity of asoalbumin lysis, therefore decreasing intensity of proteolytic collagen disintegration (cleavage). Paracetamol, diclofenac and dexamethasone decrease proteolysis of low-molecular proteins, but they essentially raise collagenalytic activity of the anterior chamber aqueous humor of rabbit eyes due to penetrating corneal and iris injury.

Key words: eye, cornea, iris, injury, prostaglandins, proteolysis.

Bukovinian State Medical University (Chernivtsi)

Надійшла 07.05.2014 p. Рецензент - проф. Герасимюк I.С (Тернопіль) 